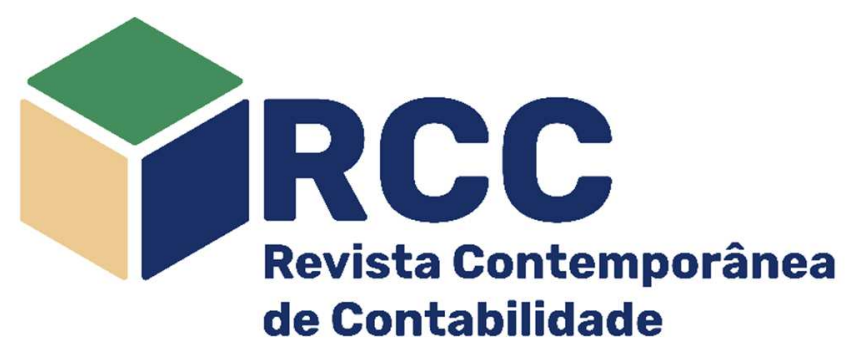

\title{
Qual a influência da gestão familiar no custo de financiamento da dívida? Análise em companhias com estrutura de propriedade familiar
}

\author{
What is the influence of family management on the cost of debt financing? Analysis in companies \\ with family ownership structure
}

\begin{abstract}
¿Cuál es la influencia de la gestión familiar en el costo de la financiación de la deuda? Análisis en compañías con estructura de propiedad familiar
\end{abstract}

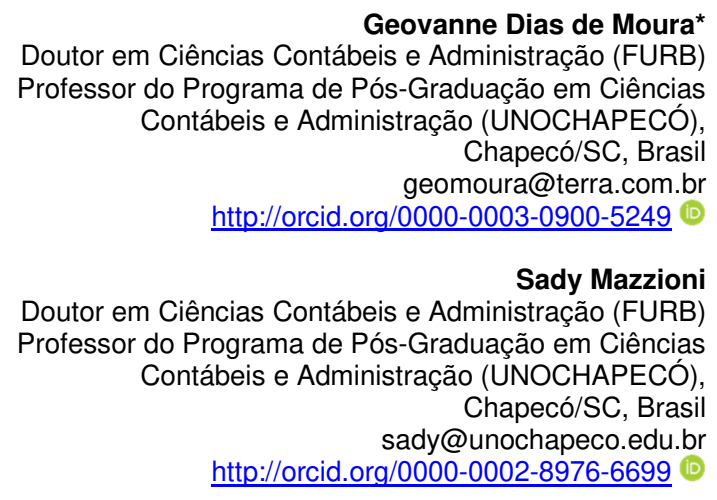

Geovanne Dias de Moura*

Doutor em Ciências Contábeis e Administração (FURB)

Contábeis e Administração (UNOCHAPECÓ),

Chapecó/SC, Brasil

geomoura@icter

Sady Mazzioni

Doutor em Ciências Contábeis e Administração (FURB)

do Programa de Pós-Graduação em Ciências Chapecó/SC, Brasil
ChNOCHAPECÓ),

sady@unochapeco.edu.br

Endereço do contato principal para correspondência* Avenida Senador Attílio Fontana - Servidão Anjo da Guarda, 295-D - Bairro Efapi, CEP: 89809-900 - Chapecó/SC, Brasil

\section{Resumo}

O estudo verificou a influência da gestão familiar no custo de financiamento da dívida de companhias com estrutura de propriedade familiar. Realizou-se pesquisa descritiva, quantitativa e documental, com consulta aos Formulários de Referência, banco de dados Economática e site da B3, utilizando-se de dados de 2012 a 2016. As companhias foram classificadas como familiares quando o último acionista controlador era uma família. Para identificar o tipo de gestão investigou-se a participação das famílias na diretoria executiva e no conselho de administração. O custo da dívida foi calculado pela razão entre despesas financeiras e passivo oneroso médio. Constatou-se que as variáveis que captavam a existência de gestão familiar eram estatisticamente significantes e com coeficientes negativos, denotando que a gestão familiar influenciava para redução do custo de financiamento da dívida. Assim, a pesquisa adiciona contribuições para a literatura com evidências empíricas relativas ao cenário brasileiro, ainda carente de pesquisas dessa natureza.

Palavras-chave: Gestão familiar; Custo de financiamento da dívida; Estrutura de propriedade familiar

\begin{abstract}
The study verified the influence of family management on the debt cost of companies with family ownership structure. A descriptive, quantitative and documentary research was carried out, with reference to the Reference Forms, Economática database and B3's website, using data from 2012 to 2016. The companies were classified as relatives when the last controlling shareholder was a family. To identify the type of management, the participation of the families in the executive board and the board of directors was investigated. The cost of debt was calculated by the ratio of financial expenses to average onerous liabilities. It was found that the variables that captured the existence of family management were statistically significant and with negative coefficients, denoting that family management influenced to reduce the cost of debt
\end{abstract}


financing. Thus, the research adds contributions to the literature with empirical evidence regarding the Brazilian scenario, still lacking in research of this nature.

Keywords: Family management; Cost of debt financing; Family owned structure

\section{Resumen}

Se verificó la influencia de la gestión familiar en el costo de financiamiento de la deuda de compañías con estructura de propiedad familiar. Investigación descriptiva, cuantitativa y documental en el período de 2012 a 2016. Las compañías fueron clasificadas como familiares cuando el último accionista controlador era familiar. Para identificar el tipo de gestión se investigó la participación de las familias en la dirección ejecutiva y en el consejo de administración. El coste de la deuda se calculó por la razón entre los gastos financieros y el pasivo oneroso medio. Se constató que las variables que captaban la existencia de gestión familiar eran estadísticamente significantes y con coeficientes negativos, denotando que la gestión familiar influía para reducir el costo de financiamiento de la deuda. Así, la investigación añade contribuciones a la literatura con evidencias empíricas relativas al escenario brasileño, aún carente de investigaciones de esa naturaleza.

Palabras clave: Gestión familiar; Costo de financiación de la deuda; Estructura de propiedad familiar

\section{Introdução}

As empresas financiam seus ativos por meio de uma combinação entre capital próprio e capital de terceiros, sendo que este mix é denominado de estrutura de capital. De modo geral, os capitais próprios são os recursos fornecidos pelos sócios ou acionistas, enquanto os capitais de terceiros envolvem os recursos obtidos por meio de dívidas (financiamentos bancários, debêntures, bonds, etc.) (ARDALAN, 2017; LE; BICH, 2017).

Em relação à estrutura de capital, diversos autores, a exemplo de Shailer e Wang (2015), Derrien, Kecskés e Mansi (2016), Ardalan (2017), Ghouma, Ben-Nasr e Yan (2017) e Le e Bich (2017), destacam que o custo do capital próprio é maior do que o custo da dívida. Isso ocorre porque os acionistas das empresas sempre recebem os dividendos depois que os credores da dívida recebem os seus juros, seja quando a empresa está em operação ou quando está em estado de falência. Portanto, os acionistas estão expostos a um maior nível de risco do que os credores da dívida e, consequentemente, exigirão uma maior taxa de retorno, o que significa um maior custo (ARDALAN, 2017).

O uso da dívida possui muitas vantagens em relação ao capital próprio. Em primeiro lugar, as empresas se beneficiam com os aspectos fiscais, haja vista que os impostos sobre o resultado são calculados depois que os juros são pagos aos credores. Em segundo lugar, as dívidas podem desempenhar um papel de monitoramento interno, pois as empresas mais alavancadas tendem a prestar mais atenção às reações dos mercados de dívida. Terceiro, a dívida pode sinalizar confiança dos credores ao mercado, de modo geral, levando a menores custos de financiamentos futuros (GHOUMA; BEN-NASR; YAN, 2017).

Assim, os financiamentos formais são uma forma importante que as empresas, principalmente de países emergentes, possuem para obter recursos, visto que nesses países o mercado acionário tende a ser pouco desenvolvido (SHAILER; WANG, 2015). Destaca-se que esse é o cenário do Brasil, um país code-law (direito codificado), com mercado de ações em desenvolvimento e com proteção legal dos direitos de propriedade significativamente mais baixos do que em mercados mais desenvolvidos, como Estados Unidos e Reino Unido (common-law). Isso implica que as ações das empresas tendem a apresentar riscos mais elevados (IATRIDIS, 2012; MOURA, 2014).

Diferente de países como os Estados Unidos, Japão e Reino Unido, por exemplo, onde a propriedade acionária das empresas é dispersa, na maioria dos outros países, sejam desenvolvidos ou em desenvolvimento, a propriedade acionária ainda está concentrada em famílias (SIREGAR; UTAMA, 2008; FAN; WEI; XU, 2011; MOURA, 2014). Conforme descreve Moura (2014), este cenário é observado na literatura que aborda o tema, principalmente a partir do estudo de La Porta, Lopez-de-Silanes e Shleifer (1999), que analisaram a estrutura de controle em 27 países e verificaram que a estrutura de propriedade familiar era um tipo dominante entre as companhias abertas.

A partir do papel importante que as empresas familiares desempenham no desenvolvimento e crescimento econômico dos países, pesquisadores têm investigado a influência das famílias na composição da estrutura de capital das empresas (GONZÁLEZ et al., 2013; HAMID; ABDULLAH; KAMARUZZAMAN, 2015; DÍAZ-DÍAZ; GARCÍA-TERUEL; MARTÍNEZ-SOLANO, 2016). E, em razão da importância da dívida, mais especificamente, as investigações também têm abordado a influência das famílias no custo de financiamento da dívida das empresas (TANAKA, 2014; HASHIM; AMRAH, 2016; MA; MA; TIAN, 2017).

Em relação à influência das famílias no custo da dívida, pesquisadores têm argumentado que as famílias são um tipo de agente mais interessado na sobrevivência das empresas, pois, muitas vezes, detêm carteiras de investimento não diversificadas, no comparativo com outros tipos de acionistas. Também são investidores que procuram passar a empresa aos herdeiros, ou seja, as famílias consideram suas empresas como um legado a ser repassado para gerações futuras e não como uma riqueza para ser consumida durante suas vidas. Assim, os incentivos exclusivos das famílias sugerem que esse tipo de acionista pode reduzir conflitos de agência com os fornecedores da dívida. Logo, empresas familiares apresentariam menores custos 
de dívida em relação às empresas não familiares (ANDERSON; MANSI; REEB, 2003; BOUBAKRI; GHOUMA, 2010; TANAKA, 2014).

No entanto, uma perspectiva alternativa seria que as famílias podem agravar os conflitos de agência, uma vez que, na maioria dos casos, possuem voz e poder de forçar a empresa a atender suas demandas em detrimento dos minoritários. Então, se as famílias aumentam os conflitos de agência, os fornecedores da dívida tenderiam a exigir maiores juros das empresas familiares para compensar o risco superior (ANDERSON; MANSI; REEB, 2003; BOUBAKRI; GHOUMA, 2010; LIN et al., 2011; TANAKA, 2014). Contudo, as evidências em relação a cada uma dessas duas perspectivas ainda são inconclusivas, conforme salientam Lin et al. (2011), Tanaka (2014) e Hashim e Amrah (2016), por exemplo.

Nesse contexto, a questão de pesquisa que orienta este estudo é: Em companhias com estrutura de propriedade familiar, qual a influência da gestão familiar no custo de financiamento da dívida? Assim, o objetivo da pesquisa é verificar a influência da gestão familiar no custo de financiamento da dívida de companhias com estrutura de propriedade familiar.

Os fatores que influenciam no custo do endividamento investigados por pesquisadores brasileiros foram a concentração acionária (KONRAHT; CAMARGO; VICENTE, 2016), nível de evidenciação de informações (LIMA, 2009; ANGONESE et al., 2013), qualidade da informação (CASTRO; MARTINEZ, 2009; NARDI; NAKAO, 2009; MOURA et al., 2016), responsabilidade socioambiental (FERNANDES, 2013 et al., 2015) e governança corporativa (CAROPREZO, 2011; BARROS; SILVA; VOESE, 2015; FONSECA; SILVEIRA, 2016).

Sendo assim, a relevância do estudo está no fato dele relacionar o custo da dívida com um fator ainda não investigado por pesquisadores brasileiros, mas já apontado na literatura internacional. Também adiciona contribuições para a literatura com evidências empíricas relativas ao cenário brasileiro, ainda carente de pesquisas dessa natureza.

\section{Referencial Teórico}

Nesta subseção discorre-se, em um primeiro momento, sobre o tema estrutura de capital, após, tratase, de forma mais específica, sobre o custo de financiamento da dívida em empresas familiares. Em seguida apresentam-se estudos anteriores sobre a influência da gestão familiar no custo de financiamento da dívida.

\subsection{Estrutura de Capital}

As empresas, conforme já descrito, financiam seus ativos por meio de uma combinação entre o capital próprio e o capital de terceiros, sendo que este mix é denominado de estrutura de capital. Os capitais próprios, de modo geral, são os recursos fornecidos pelos sócios ou acionistas, enquanto os capitais de terceiros englobam os recursos obtidos por meio de dívidas, a exemplo dos financiamentos bancários, debêntures, bonds, dentre outros. (ARDALAN, 2017; LE; BICH, 2017).

O tema estrutura de capital é um assunto relevante e intensamente discutido pelos pesquisadores da área de administração, economia e contabilidade. Ressalta-se que o interesse por esse assunto aumentou, especialmente, a partir do trabalho clássico de Modigliani e Miller (1958), no qual os autores postularam que o valor da empresa não era influenciado pela estrutura de capital. De forma mais específica, descreveram que o valor da empresa seria determinado pelos seus próprios ativos, não pela proporção de dívida ou patrimônio emitido (ARDALAN, 2017; LE; BICH, 2017).

Tal proposição, na época, contrariou a teoria convencional representada principalmente por Durand (1952) que defendia a existência de uma estrutura de capital ótima, capaz de minimizar o custo de capital da empresa e maximizar o seu valor. Essa discussão deu origem a um grande número de pesquisas centradas no entendimento da forma como as empresas se financiam (LE; BICH, 2017; VO, 2017).

A teoria de Modigliani e Miller (1958), segundo Le e Bich (2017), era baseada em pressupostos restritivos de um mercado de capitais perfeito que não existia no mundo real. Então, os pesquisadores passaram a avaliar a questão também levando em conta as imperfeições existentes no mercado, como impostos, custos de falência, custos de agência e assimetria de informações. Assim, de acordo com os autores, novas teorias passaram a ser utilizadas em estudos sobre estrutura de capital, sendo que as três principais são a teoria do pecking order, teoria do trade-off e a teoria da agência.

A teoria do pecking order, oriunda principalmente do estudo de Myers (1984) e de Myers e Majluf (1984), considera a existência de uma hierarquia nas fontes de financiamento, ou seja, assume que as empresas devem dar prioridade às fontes de financiamento com um nível de esforço menor: $1^{\circ}$ ) autofinanciamento; $2^{\circ}$ ) recursos de terceiros; $3^{\circ}$ ) recursos captados por meio de emissão de novas ações. A ideia é que os lucros acumulados reduziriam a necessidade da utilização de capitais de terceiros (ARDALAN, 2017; LE; BICH, 2017; VO, 2017).

Com base na teoria do trade-off, que teve origem principalmente a partir de Myers (1984), à medida que aumenta o endividamento de uma empresa, aumenta também o seu benefício fiscal, levando a empresa a aumentar o seu valor. Porém, à medida que aumenta a dívida, também tende a aumentar os custos associados às dificuldades financeiras. Consequentemente, a empresa deve ir contrabalançando os impactos 
do benefício fiscal com as dificuldades financeiras, de forma a atingir um ponto de endividamento que maximize o valor da empresa (ARDALAN, 2017; LE; BICH, 2017; VO, 2017).

A teoria da agência, desenvolvida a partir de Jensen e Meckling (1976), pressupõe que uma estrutura de capital ótima para maximizar o valor da empresa deve ser aquela que minimiza os conflitos de interesse entre as partes interessadas (GRAHAM; LEARY; ROBERTS, 2015, ARDALAN, 2017; LE; BICH, 2017).

Em estudos sobre empresas familiares, de acordo com diversos autores, tais como Villalonga e Amit (2006), Young et al. (2008), Mazzi (2011) e Moura (2014), a teoria da agência tem sido a mais utilizada. E, tem se concentrado tanto nas relações entre principal e agente, ou seja, entre proprietários e gestores, quanto nas relações entre principal e principal, ou seja, entre famílias, minoritários e outros stakeholders. Nesse sentido, Villalonga e Amit (2006), com foco em empresas familiares, se referem ao conflito principal-agente como Problema de Agência I e ao conflito principal-principal como Problema de Agência II.

Na perspectiva do principal-agente, os conflitos de interesses ocorrem principalmente entre acionistas e diretores, já que a propriedade e a gestão são separadas. Então, quando o controle é familiar e o diretor presidente também é membro da família, os conflitos podem ser atenuados e o desempenho melhorado, pois os interesses entre propriedade e gestão estão altamente alinhados (PENG; JIANG, 2010; CAI; LUO; WAN, 2012; LIU; YANG; ZHANG, 2012).

Sob a ótica do principal-principal, os conflitos ocorrem principalmente entre acionistas majoritários, minoritários e outros stakeholders. Nessa abordagem, uma gestão familiar contribui para que os proprietários familiares (majoritários) possam expropriar os minoritários e outros stakeholders. Por isso, o conflito principalprincipal pode ser mais comum em empresas familiares (YOUNG et al., 2008; PENG; JIANG, 2010; LIU, YANG; ZHANG, 2012).

Autores como Ardalan (2017), Le e Bich (2017) e Vo (2017) mencionam que as diversas teorias existentes têm contribuído para o desenvolvimento do tema estrutura de capital, que continua sendo uma questão central, relevante e que ainda carece de investigações. Além disso, estudos (BRADLEY; PANTZALIS; YUAN, 2016; CHEN et al., 2016; DERRIEN; KECSKÉS; MANSI, 2016; LI; RICHIE, 2016; GHOUMA; BENNASR; YAN, 2017; LIEDONG; RAJWANI, 2017) têm demonstrado que a definição da estrutura de capital, em um cenário de dinâmicas complexas, está diretamente relacionada com o custo do financiamento.

\subsection{Custo de Financiamento da Dívida em Companhias Familiares}

Na literatura, diversos pesquisadores, tais como Lai (2011), Byun et al. (2013), Waisman (2013), Ge e Liu (2015), Li e Richie (2016) e Ghouma, Ben-Nasr e Yan (2017) têm mencionado que o uso do capital de terceiros, por meio da dívida, possui vantagens em relação ao capital próprio. Como exemplos, Ghouma, BenNasr e Yan (2017) citam os benefícios fiscais, o papel de monitoramento interno da dívida e uma possível sinalização de confiança dos credores ao mercado. Outro aspecto é que os financiamentos formais são uma forma importante que as empresas de países emergentes, caso do Brasil, possuem para obter recursos, visto que nesses países o mercado acionário tende a ser pouco desenvolvido (SHAILER; WANG, 2015; MA; MA; TIAN, 2017).

Ao buscar financiamentos, as empresas devem realizar uma análise detalhada, a fim de escolher dentre as alternativas existentes no mercado, aquelas mais benéficas e menos onerosas (BARROS; SILVA; VOESE, 2015). Desta forma ao buscar um financiamento, a empresa depara-se com o custo de financiamento da dívida, que está diretamente ligado à taxa de juros praticada pelo mercado ou pelo agente financiador. Por sua vez, o agente financiador, a fim de definir a taxa de juros, faz uma análise detalhada das variáveis que podem envolver o negócio.

Os custos de agência da dívida, de acordo com Jensen e Meckling (1976), são caracterizados em três tipos. O primeiro é caracterizado quando a empresa capta recursos de terceiros, desta forma, o risco das decisões do gestor é compartilhado com os credores/financiadores da empresa. Na sequência, quando o credor financia uma empresa incorre em gastos de monitoramento quanto ao desempenho e reflexos das decisões tomadas. E, por fim, há o custo de agência de dívida atrelado a prejuízos decorrentes da irrecuperabilidade do capital emprestado.

As famílias possuem um forte ímpeto para atuar de forma correta e melhorar o desempenho da empresa, visando a transferência da empresa para outros membros da família ou para os descendentes. Assim, as famílias procuram gerir a empresa para a sobrevivência, maximizando o valor da empresa e não o valor para o próprio acionista. Como os financiadores da dívida também se beneficiam de um maior valor da empresa, esse incentivo exclusivo da empresa familiar poderia ajudar a mitigar os conflitos de agência com os detentores da dívida (TANAKA, 2014).

Além disso, as famílias têm maior preocupação com a reputação perante terceiros. As empresas familiares geralmente experimentam rotatividade infrequente de gerentes e diretores. Deste modo, a propriedade familiar favorece relacionamentos fortes com seus stakeholders. O relacionamento de longo prazo estabelecido por meio da reputação familiar é altamente desejável para os fornecedores da dívida porque as famílias continuam a manter o desempenho da empresa a longo prazo (ANDERSON; MANSI; REEB, 2003; TANAKA, 2014). 
Mesmo quando a gestão da empresa não é familiar, as famílias têm um maior incentivo para monitorar e disciplinar a gestão, aumentando assim o desempenho da empresa. Essas atividades de monitoramento beneficiam os devedores e, portanto, ajudam a mitigar o conflito entre o acionista e os detentores de títulos de dívida, resultando em uma redução no risco de inadimplência. Logo, se os detentores de títulos de dívida preveem esses incentivos, as empresas familiares tendem a desfrutar de menor custo da dívida (LIN et al., 2011; TANAKA, 2014).

Por outro lado, as empresas familiares também podem extrair os benefícios privados de controle à custa de outros stakeholders, incluindo os fornecedores da dívida (BOUBAKRI; GHOUMA, 2010). O comportamento oportunista das famílias poderia agravar o conflito entre os acionistas e os detentores de títulos de dívida, levando a um aumento no risco de inadimplência. Quando os detentores de títulos reconhecem tal risco, as empresas familiares tenderiam a apresentar maior custo da dívida (ANDERSON; MANSI; REEB, 2003; TANAKA, 2014).

Além disso, as famílias geralmente evitam captar recursos pelo mercado de ações, porque este tipo de operação envolve risco de perda do controle, haja vista que podem diminuir a concentração acionária do controlador. Assim, espera-se que empresas com estrutura de propriedade familiar priorizem financiamentos bancários, o que levaria a uma maior alavancagem financeira, por consequência, poderia aumentar o risco e o custo da dívida (BOUBAKRI; GHOUMA, 2010).

No entanto, na literatura, os resultados acerca da influência das famílias no custo da dívida das empresas ainda são bastante divergentes, pois, enquanto alguns autores identificaram influência positiva, outros encontraram o inverso. Sendo assim, este assunto ainda apresenta lacunas que requerem investigações, conforme pode ser verificado de forma mais detalhada por meio dos estudos anteriores que serão descritos na sequência.

\subsection{Estudos Anteriores Sobre a Influência da Gestão Familiar no Custo da Dívida}

A seguir, são descritos alguns estudos similares que analisaram questões relacionadas a gestão familiar e custo da dívida. Inicia-se pela pesquisa de Anderson, Mansi e Reeb (2003) que investigaram uma amostra de 252 companhias abertas americanas constantes na base Lehman Brothers Bond Database (LBBD) e no índice Standard e Poor's (S\&P) 500, que possuíam dados disponíveis no período de 1993 a 1998. Os resultados evidenciaram que quando os membros da família ocupavam a posição de CEO, o custo do financiamento da dívida era maior em relação às empresas familiares com CEOs externos.

Lin et al. (2011) verificaram a influência da gestão familiar e dos excessos de direitos de votos dos controladores no custo de financiamento da dívida de companhias abertas. A análise ocorreu em um conjunto de empresas de 22 países da Ásia Oriental e da Europa Ocidental que possuíam dados para o período de 1996 a 2008. Os autores destacaram que as famílias geralmente limitavam os cargos de direção executiva aos membros da família para fortalecer ainda mais o poder de controle sobre a empresa e, por isso, era importante analisar também a influência da gestão no custo da dívida. Em relação a essa questão, verificaram que os custos de financiamento da dívida eram ainda mais elevados em empresas de controle familiar que também possuíam o cargo de CEO ocupado por algum membro da família controladora.

Tanaka (2014) explorou a relação entre mecanismos de governança corporativa e o custo de financiamento da dívida de companhias abertas. Entre os vários mecanismos de governança corporativa, 0 foco do autor foi à participação acionária do CEO, a propriedade e gestão familiar e a concentração acionária de grandes acionistas. Investigou uma amostra composta por 196 companhias abertas japonesas com dados disponíveis no período de 2005 a 2008. A análise empírica revelou que a participação acionária do CEO estava positivamente associada ao custo da dívida, sugerindo que os detentores de títulos preocupam-se com os conflitos de interesse com o CEO e, portanto, exigem maiores rendimentos para as empresas que possuem CEO com maior participação acionária. Os resultados também revelaram que a propriedade familiar estava positivamente correlacionada com o custo da dívida, segundo o autor, indicando preocupações dos credores com a possibilidade de existirem maiores conflitos de agência nesse tipo de empresa. Não identificaram influência da gestão familiar no custo da dívida na maioria dos testes realizados.

Ma, Ma e Tian (2017) analisaram uma amostra composta por 705 companhias abertas chinesas no período de 2004 a 2010 e investigaram o impacto do tipo de CEO no custo da dívida. Descobriram que apenas empresas com CEOs familiares desfrutavam de menor custo da dívida. Sendo assim, concluíram que empresas com estrutura e gestão familiares apresentavam menos problemas e ressaltaram que nas companhias familiares chinesas o efeito alinhamento superava o efeito entrincheiramento.

Depreende-se, a partir dos artigos descritos, que as justificativas para fundamentar os resultados baseiam-se principalmente na Teoria da Agência, a partir da perspectiva do efeito alinhamento e do efeito entrincheiramento. Quando o efeito alinhamento é percebido nas empresas familiares, pelos credores, há maior probabilidade de o custo de financiamento da dívida ser menor. Por outro lado, quando o efeito entrincheiramento é percebido como dominante, aumenta a probabilidade de o custo de financiamento da dívida ser maior. Percebe-se também a existência de resultados divergentes, pois, enquanto alguns autores identificaram maior custo da dívida em empresas de gestão familiar, outros encontraram o inverso. Sendo assim, este assunto ainda apresenta lacunas que requerem investigações. Nota-se, ainda, por meio dos 
estudos apresentados, que as investigações ocorreram em empresas americanas, europeias e asiáticas. Deste modo, este assunto merece atenção em outros países, como no caso do Brasil.

\section{Procedimentos Metodológicos}

Para atender ao objetivo proposto realizou-se pesquisa descritiva, documental e de abordagem quantitativa. A amostra, conforme citado por Silveira (2004, p. 111), pode ser entendida como "[...] uma parte escolhida, segundo critérios de representatividade, na população". Neste estudo é considerada intencional, não probabilística e compreendeu as companhias abertas familiares listadas na B3.

Para definir a amostra, inicialmente, em razão das peculiaridades do setor, em cada ano, foram excluídas as companhias que exerciam atividades financeiras. Em seguida, foram identificadas todas as companhias familiares que possuíam dados disponíveis para o cálculo de todas as variáveis da pesquisa. Após estes procedimentos, a amostra foi composta por 113 companhias familiares em 2012, 116 em 2013, 123 em 2014, 123 em 2015 e 125 em 2016.

Portanto, a pesquisa foi realizada com dados de um período de 5 anos (2012 a 2016). Em relação ao período de análise é importante destacar que o ano de 2010 constitui o período inicial de adoção plena das normas internacionais de contabilidade (IFRS) no Brasil. Nesse sentido, Santos, Ponte e Mapurunga (2014) realizaram uma análise do nível de conformidade com a divulgação requerida pelo padrão International Financial Reporting Standards (IRFS) no primeiro ano (2010) de adoção plena das normas no Brasil. De modo geral, investigaram 638 itens de divulgação obrigatória, requeridos por 28 IFRS, para 366 companhias brasileiras não financeiras listadas na BM\&FBovespa. Os resultados apontaram para níveis presumivelmente baixos de cumprimento das exigências de divulgação.

Como justificativa para o baixo nível de conformidade, Santos, Ponte e Mapurunga (2014) descrevem que 2010 foi um primeiro passo de aprendizagem para as empresas brasileiras na assimilação de um sistema contábil novo, fundado em tradições culturais e institucionais (common law) diferentes das raízes da contabilidade brasileira (codelaw). Por isso, de acordo com os autores, dificilmente se poderia esperar que todas as normas fossem radicalmente incrementadas no primeiro ano de adoção no Brasil.

Deste modo, para reduzir vieses nos cálculos de alguma das variáveis deste estudo, optou-se por excluir os dois primeiros anos de adoção plena das normas internacionais da análise. Então, a investigação se concentrou no período de 2012 a 2016, a fim de estabelecer um corte temporal capaz de contribuir para a literatura.

As companhias foram classificadas como familiares nos casos em que o último acionista controlador era uma família ou um indivíduo (em termos de direitos de voto), com participação mínima de 10\%, assim como no estudo de La Porta, Lopez-de-Silanes e Shleifer (1999) rastrearam a cadeia de propriedade até identificar o último acionista controlador. O último acionista controlador era aquele que, de forma direta ou indireta, possuía o controle da empresa. Os autores fizeram uma distinção entre cinco tipos de proprietários finais: 1) família ou um indivíduo; 2) Estado; 3) instituição financeira, como um banco ou uma companhia de seguros; 4) uma empresa amplamente difundida; 5) diversos, como uma cooperativa ou um grupo com nenhum investidor controlador.

No entanto, como o interesse central desta pesquisa é a estrutura de propriedade familiar, foram identificadas apenas as empresas familiares. Este procedimento é similar ao realizado em estudos internacionais anteriores que verificaram a influência das famílias no custo da dívida, tais como Anderson, Mansi e Reeb (2003), Steijvers e Voordeckers (2009), Boubakri e Ghouma (2010), Lin et al. (2011), Khan et al. (2013), Tanaka (2014), Hashim e Amrah (2016) e Ma, Ma e Tian (2017).

Para identificar o tipo de gestão adotou-se critérios semelhantes aos de Villalonga e Amit (2006), Boubakri e Ghouma (2010), Lin et al. (2011), Tanaka (2014) e Ma, Ma e Tian (2017), que investigaram a participação das famílias na diretoria executiva e no conselho de administração, conforme Quadro 1.

\begin{tabular}{|c|c|c|c|}
\hline Variáveis & Métricas & Fonte dos dados & Autores de base \\
\hline $\begin{array}{l}\text { Diretor Presidente } \\
\text { (DirPres_Fam) }\end{array}$ & $\begin{array}{c}\text { DirPres_Fam: } \\
\text { Familiar }=1 \\
\text { Não familiar }=0\end{array}$ & \multirow{3}{*}{$\begin{array}{c}\text { Formulário de Referência: } \\
\text { Seção } 12.6 \text { - Composição e } \\
\text { experiência profissional da } \\
\text { administração e do Conselho } \\
\text { Fiscal; } \\
\text { Seção } 12.9 \text { - Relações } \\
\text { familiares. }\end{array}$} & \multirow{3}{*}{$\begin{array}{c}\text { Villalonga e Amit (2006); } \\
\text { Boubakri e Ghouma (2010); Lin } \\
\text { et al. (2011); Tanaka (2014); } \\
\text { Ma, Ma e Tian (2017). }\end{array}$} \\
\hline $\begin{array}{c}\text { Presidente do Conselho de } \\
\text { Administração (PresCA_Fam) }\end{array}$ & $\begin{array}{l}\text { PresCA_Fam: } \\
\text { Familiar }=1 \\
\text { Não familiar }=0\end{array}$ & & \\
\hline $\begin{array}{c}\text { Diretor Presidente e } \\
\text { Presidente do Conselho de } \\
\text { Administração } \\
\text { (DirPres\&PresCA_Fam) }\end{array}$ & $\begin{array}{c}\text { DirPres\&PresCA_Fam: } \\
\text { Familiar }=1 \\
\text { Não familiar }=0\end{array}$ & & \\
\hline
\end{tabular}

Fonte: elaboração própria.

Nota-se no Quadro 1 que foram criadas três variáveis dummy, que receberam valor "1" nos casos em que o "diretor presidente (DirPres_Fam)", o "presidente do Conselho de Administração (PresCA_Fam)" e ainda quando o "Diretor Presidente e o Presidente do Conselho de Administração (DirPres\&PresCA_Fam)", 
de forma combinada, eram o fundador da empresa, ou então, um membro por sangue ou casamento, pertencente à família controladora, ou valor "0" caso contrário.

Portanto, nesta pesquisa é analisada a participação das famílias na diretoria executiva e no conselho de administração e assim como no estudo de Villalonga e Amit (2006) e em outros estudos subsequentes, tais como de Boubakri e Ghouma (2010), Lin et al. (2011), Tanaka (2014) e Ma, Ma e Tian (2017) os dados relativos à gestão correspondem ao ano $t_{-1}$ em relação ao custo da dívida. A justificativa é pautada no fato de que as decisões do passado impactam nas operações empresariais do presente. Ressalta-se que os dados foram coletados manualmente, em cada ano, para cada empresa da amostra, nos Formulários de Referência, na Seção 12.6 - Composição e experiência profissional da administração e do Conselho Fiscal e na Seção 12.9 - Relações familiares.

Então, quando se verifica a influência da gestão familiar no custo de financiamento da dívida do ano de 2016, os dados sobre gestão correspondem ao ano de 2015. O mesmo ocorre em relação ao custo da dívida do período 2012 a 2015, em que os dados sobre gestão correspondem ao período 2011 a 2014 . A métrica utilizada para identificar o custo da dívida das companhias da amostra é descrita no Quadro 2.

Quadro 2 - Proxy para o custo de financiamento da dívida
\begin{tabular}{|c|c|c|c|}
\hline Variável & Métricas & Fonte dos dados & Autores de base \\
\hline $\begin{array}{c}\text { Custo de financiamento da } \\
\text { dívida } \\
\text { (Custo_Dív) }\end{array}$ & $\begin{array}{c}\text { Custo_Dív: } \\
\text { Despesas financeiras }\end{array}$ & $\begin{array}{c}\text { Banco de dados } \\
\text { Economática }\end{array}$ & $\begin{array}{c}\text { Lima (2009); Lin et al. (2011); Tanaka } \\
\text { (2014); Barros, Silva e Voese (2015); } \\
\text { Fonseca e Silveira (2016); Ma, Ma e } \\
\text { Tian (2017). }\end{array}$ \\
\hline
\end{tabular}

Fonte: elaboração própria.

Observa-se no Quadro 2 que para identificar o custo de financiamento da dívida, em consonância com estudos anteriores (Lima, 2009; Lin et al., 2011; Tanaka, 2014; Barros et al., 2015; Fonseca \& Silveira, 2016; Ma et al., 2017), foi calculado, em cada ano, para cada empresa, a razão entre as despesas financeiras e o passivo oneroso médio do ano. O passivo oneroso foi representado pelos empréstimos e financiamento de curto e longo prazo, incluindo as debêntures emitidas. Por fim, foram coletados os dados das variáveis de controle, que também podem influenciar no custo do financiamento da dívida, conforme Quadro 3.

\begin{tabular}{|c|c|c|c|}
\hline Variável & Métrica & & Autores de base \\
\hline $\begin{array}{l}\text { Idade da empresa } \\
\text { (Idade_Cia) }\end{array}$ & $\begin{array}{l}\text { Idade da empresa, medida pelo } \\
\text { número de anos decorridos desde a } \\
\text { data de fundação constante no } \\
\text { registro da CVM }\end{array}$ & $\begin{array}{c}\text { Formulário de Referência: } \\
\text { Dados cadastrais - Dados } \\
\text { gerais }\end{array}$ & $\begin{array}{l}\text { Steijvers e Voordeckers } \\
\text { (2009); Tanaka (2014). }\end{array}$ \\
\hline $\begin{array}{l}\text { Governança } \\
\text { Corporativa } \\
\text { (N_GC) }\end{array}$ & $\begin{array}{l}\text { Listada em nível diferenciado de } \\
\text { governança da B3: } \\
\text { Sim }=1 \text { / Não }=0\end{array}$ & $\begin{array}{l}\text { Web site } \\
\text { da B3 }\end{array}$ & $\begin{array}{c}\text { Barros, Silva e } \\
\text { Voese (2015); Fonseca e } \\
\text { Silveira (2016). } \\
\end{array}$ \\
\hline Endividamento & $\begin{array}{l}\text { (Passivo circulante + Passivo não } \\
\text { circulante) / Ativo total }\end{array}$ & $\begin{array}{l}\text { Banco de dados } \\
\text { Economática }\end{array}$ & $\begin{array}{c}\text { Boubakri e Ghouma (2010); } \\
\text { Khan et al. (2013); Tanaka (2014); } \\
\text { Ma, Ma e Tian (2017). }\end{array}$ \\
\hline $\begin{array}{l}\text { Tamanho da } \\
\text { Empresa } \\
\text { (Tamanho) }\end{array}$ & $\begin{array}{c}\text { Logaritmo natural do valor } \\
\text { contábil dos ativos totais } \\
\text { da empresa }\end{array}$ & $\begin{array}{l}\text { Banco de dados } \\
\text { Economática }\end{array}$ & $\begin{array}{c}\text { Anderson, Mansi e Reeb (2003); Lin } \\
\text { et al. (2011); Tanaka (2014); Hashim } \\
\text { e Amrah (2016); Ma, Ma e Tian } \\
\text { (2017). }\end{array}$ \\
\hline $\begin{array}{l}\text { Retorno sobre } \\
\text { ativos (ROA) }\end{array}$ & $\mathrm{ROA}=$ Ebitda/Ativo total & $\begin{array}{l}\text { Banco de dados } \\
\text { Economática }\end{array}$ & $\begin{array}{c}\text { Anderson, Mansi e Reeb (2003); } \\
\text { Boubakri e Ghouma (2010); Lin et al. } \\
\text { (2011); Tanaka (2014); Hashim e } \\
\text { Amrah (2016). }\end{array}$ \\
\hline $\begin{array}{l}\text { Crescimento da } \\
\text { Empresa } \\
\text { (Crescim) }\end{array}$ & $\begin{array}{c}\text { Taxa de crescimento } \\
\text { dos ativos }\end{array}$ & $\begin{array}{l}\text { Banco de dados } \\
\text { Economática }\end{array}$ & $\begin{array}{l}\text { Bliss e Gul (2012); Tanaka (2014); } \\
\text { Shailer e Wang (2015); Ma et al. } \\
\text { (2017). }\end{array}$ \\
\hline
\end{tabular}

Fonte: elaboração própria.

Observa-se no Quadro 3 que as variáveis de controle utilizadas foram a idade da empresa, governança corporativa, endividamento, tamanho, ROA e o crescimento da empresa:

a) Idade da empresa: empresas que atuam há mais tempo no mercado apresentam melhores mecanismos de gestão que auxiliam na obtenção de vantagem competitiva. Além disso, normalmente, estabelecem reputações favoráveis e boas relações com os diversos stakeholders. Sendo assim, empresas mais antigas tendem a ter menores custos da dívida (STEIJVERS; VOORDECKERS, 2009; TANAKA, 2014).

b) Governança corporativa: boas práticas de governança corporativa contribuem para a redução de problemas de agência, da assimetria de informações e ajudam a proteger os interesses dos diversos stakeholders. Deste modo, empresas que possuem melhores práticas de governança tendem a apresentar menores custos da dívida (BARROS; SILVA; VOESE, 2015; FONSECA; SILVEIRA, 2016).

c) Endividamento: empresas que possuem maiores níveis de endividamento aumentam a probabilidade de falência e, portanto, tendem a pagar juros mais elevados por serem vistas como 
mais arriscadas (ANDERSON; MANSI; REEB, 2003; BOUBAKRI; GHOUMA, 2010; LIN et al., 2011; TANAKA, 2014; HASHIM; AMRAH, 2016; MA; MA; TIAN, 2017).

d) Tamanho da empresa: empresas maiores geralmente beneficiam-se de economias de escala e desempenho estável. Também apresentam capacidade superior para suportar choques negativos nos fluxos de caixa e, portanto, são menos propensas à inadimplência. Por isso, são vistas como menos arriscadas pelos credores e tendem a ter menores custos de dívida (ANDERSON; MANSI; REEB, 2003; BOUBAKRI; GHOUMA, 2010; LIN et al., 2011; TANAKA, 2014; HASHIM; AMRAH, 2016; MA; MA; TIAN, 2017).

e) ROA: empresas mais lucrativas terão menores dificuldades de pagar suas dívidas e, por isso, geralmente, apresentam menores custos de endividamento (ANDERSON; MANSI; REEB, 2003; BOUBAKRI; GHOUMA, 2010; LIN et al., 2011; TANAKA, 2014; HASHIM; AMRAH, 2016).

f) Crescimento: as empresas que se encontram em constante crescimento também podem estar sujeitas a um maior risco e, portanto, tendem a apresentar maiores custos de endividamento (BLISS; GUL, 2012; TANAKA, 2014; SHAILER; WANG, 2015; MA; MA; TIAN, 2017).

Os dados sobre "Endividamento", "Tamanho", "ROA" e "Crescimento" foram coletados no banco de dados Economática, para todo o período analisado. Os dados sobre "Governança" foram coletados manualmente no sítio da B3 e os dados referentes a idade das companhias foram coletados manualmente nos Formulários de Referência, para cada um dos anos.

Após a coleta dos dados, procedeu-se à análise. Inicialmente realizou-se o Teste-t de Student para comparar as médias do custo da dívida entre empresas que possuem gestão familiar e não familiar. O Teste$\mathrm{t}$ de Student permitiu verificar se o custo da dívida era inferior ou superior quando a gestão era familiar. Ressalta-se que foram observados os pressupostos de normalidade dos dados, por meio do teste de Kolmogorov-Smirnov; e homogeneidade de variâncias, por meio do teste de Levene.

Em seguida, foi realizada análise de regressão por mínimos quadrados ordinários para verificar a influência da gestão familiar no custo de financiamento da dívida. Foram observados os pressupostos de normalidade, por meio do teste de Kolmogorov-Smirnov; multicolinearidade, por meio do fator de inflação de variância (VIF) e Tolerance; e ausência de autocorrelção serial, por meio do teste de Durbin-Watson.

Para examinar a existência da homocedasticidade no comportamento dos resíduos, foi aplicado o teste de Pesarán-Pesarán. A realização deste teste implicou em regredir o quadrado dos resíduos padronizados (Zre_2) como função do quadrado dos resíduos estimados padronizados (Zpr_2). O teste rejeitou a hipótese nula de homocedasticidade dos resíduos. Por essa razão foi estimada a regressão por Mínimos Quadrados Ordinários (MQO) com erro padrão robusto.

\section{Descrição e Análise dos Dados}

Esta seção apresenta a descrição e a análise dos dados. Inicialmente, realizou-se a análise do tipo de gestão (familiar/não familiar) das companhias da amostra. Em seguida, apresentam-se os resultados do Teste-t de Student que permitem comparar as médias do custo do endividamento entre companhias com gestão familiar e não familiar. Por fim, são apresentados os coeficientes das regressões que possibilitam analisar a influência da gestão familiar no custo de financiamento da dívida das companhias da amostra.

$\mathrm{Na}$ Tabela 1, faz-se a exposição do tipo gestão das companhias. Os dados relacionados à gestão correspondem ao ano t-1 (2011 a 2015) em relação ao custo da dívida (2012 a 2016). Observa-se que, em relação ao cargo de diretor presidente (DirPres_Fam) que, no ano de 2011, primeiro ano da análise, 65 empresas possuíam o fundador, ou, um membro por sangue ou casamento pertencente à família controladora ocupando este cargo. Quando se analisa o percentual em relação as 113 empresas que possuíam estrutura de propriedade familiar, constata-se que em $58 \%$ delas o diretor presidente era familiar.

Destaca-se que ao longo do período de 2011 a 2015 não ocorreram grandes variações, sendo que no ano de 2015, último ano da análise, 69 empresas possuíam o diretor presidente familiar, que em termos percentuais, equivalem a $56 \%$ das 125 empresas que possuíam estrutura de propriedade familiar.

Verifica-se que estes resultados são similares aos encontrados em pesquisas anteriores, que investigaram questões relacionadas à gestão familiar, como é o caso de McConaughy (2000), que demonstrou que entre 82 grandes companhias americanas familiares de capital aberto, 54,88\% delas possuíam CEO familiar. Gómez-Mejía, Nunez-Nickel e Gutierrez (2001) demonstraram que entre 276 companhias abertas familiares da Espanha, em média, 47\% possuíam um CEO familiar. Anderson, Mansi e Reeb (2003) analisaram companhias abertas americanas e constataram que em aproximadamente $45 \%$ delas o diretor presidente era familiar. Cai, Luo e Wan (2012) demonstraram que, em média, 54,40\% das companhias chinesas analisadas eram geridas por um CEO familiar.

Quanto ao cargo de presidente do conselho de administração (PresCA_Fam), no ano de 2011, primeiro ano da análise, nota-se na Tabela 1 que 83 empresas possuíam este cargo ocupado pelo fundador, ou, um membro da família. O percentual em relação as 113 empresas que possuíam estrutura de propriedade familiar é equivalente a 73\%. Também não ocorreram grandes variações no período de 2011 a 2015 . No ano 
de 2015, último ano da análise, 85 empresas possuíam o presidente do conselho familiar, ou seja, $69 \%$ dentre as 125 empresas que possuíam estrutura de propriedade familiar.

Tabela 1 - Tipo de gestão das companhias no período de 2011 a 2015

\begin{tabular}{|c|c|c|c|}
\hline Tipo de Gestão & $\begin{array}{l}\text { Gestão } \\
\text { familiar }\end{array}$ & $\begin{array}{c}\text { Percentual em relação ao } \\
\text { total de companhias da } \\
\text { amostra }\end{array}$ & $\begin{array}{c}\text { Total de companhias da } \\
\text { amostra }\end{array}$ \\
\hline \multicolumn{4}{|c|}{2015} \\
\hline $\begin{array}{l}\text { DirPres_Fam } \\
\text { PresCA_Fam } \\
\text { DirPres\&PresCA_Fam }\end{array}$ & $\begin{array}{l}69 \\
85 \\
59 \\
\end{array}$ & $\begin{array}{l}56 \% \\
69 \% \\
48 \% \\
\end{array}$ & 125 \\
\hline \multicolumn{4}{|c|}{2014} \\
\hline $\begin{array}{l}\text { DirPres_Fam } \\
\text { PresCA_Fam } \\
\text { DirPres\&PresCA_Fam }\end{array}$ & $\begin{array}{l}67 \\
83 \\
57 \\
\end{array}$ & $\begin{array}{l}54 \% \\
67 \% \\
46 \% \\
\end{array}$ & 123 \\
\hline \multicolumn{4}{|c|}{2013} \\
\hline $\begin{array}{l}\text { DirPres_Fam } \\
\text { PresCA_Fam } \\
\text { DirPres\&PresCA_Fam }\end{array}$ & $\begin{array}{l}67 \\
85 \\
57 \\
\end{array}$ & $\begin{array}{l}54 \% \\
69 \% \\
46 \% \\
\end{array}$ & 123 \\
\hline \multicolumn{4}{|c|}{2012} \\
\hline $\begin{array}{l}\text { DirPres_Fam } \\
\text { PresCA_Fam } \\
\text { DirPres\&PresCA_Fam }\end{array}$ & $\begin{array}{l}65 \\
87 \\
61 \\
\end{array}$ & $\begin{array}{l}56 \% \\
75 \% \\
53 \% \\
\end{array}$ & 116 \\
\hline \multicolumn{4}{|c|}{2011} \\
\hline $\begin{array}{l}\text { DirPres_Fam } \\
\text { PresCA_Fam } \\
\text { DirPres\&PresCA_Fam }\end{array}$ & $\begin{array}{l}65 \\
83 \\
63\end{array}$ & $\begin{array}{l}58 \% \\
73 \% \\
56 \%\end{array}$ & 113 \\
\hline
\end{tabular}

Fonte: Dados da pesquisa.

Os percentuais identificados nesta pesquisa, próximos a 70\%, também são similares aos encontrados por Barontini e Caprio (2006), que entre as 314 companhias familiares de capital aberto pesquisadas, de 11 países da Europa Continental (Bélgica, Dinamarca, Finlândia, França, Alemanha, Itália, Holanda, Noruega, Espanha, Suécia e Suíça), no período de 1999 a 2001, 50\% possuíam o presidente do conselho familiar. Schmid (2013) constatou que na Alemanha, em 78,85\% das companhias da amostra o presidente do conselho de administração era familiar. Schmid (2013) ainda analisou um conjunto de companhias internacionais, que englobavam 9 países do Leste Asiático (Hong Kong, Indonésia, Japão, Coreia do Sul, Malásia, Filipinas, Singapura, Taiwan e Tailândia) e de 13 países da Europa Ocidental (Áustria, Bélgica, Finlândia, França, Alemanha, Irlanda, Itália, Noruega, Portugal, Espanha, Suécia, Suíça e Reino Unido), e constatou que das 4.007 companhias internacionais, $1.659(41,40 \%)$ eram de estrutura de propriedade familiar. Dentre as companhias familiares, em $48,16 \%$ delas o presidente do conselho de administração era familiar.

No tocante aos cargos de diretor presidente e presidente do conselho de administração (DirPres\&PresCA_Fam), de forma combinada, ou seja, se ambos eram ocupados por membros da família, verifica-se que, no ano de 2011, 63 empresas possuíam estes cargos ocupados pelo fundador ou por um membro da família. O percentual em relação as 113 empresas que possuíam estrutura de propriedade familiar é equivalente a 56\%. Outra vez, não ocorreram grandes variações no período de 2011 a 2015.

No ano de 2015, 59 empresas possuíam o CEO e o presidente do conselho de administração familiar, ou seja, $48 \%$ dentre as 125 empresas que possuíam estrutura de propriedade familiar. Esses percentuais são similares aos encontrados por Villalonga e Amit (2006), que entre 2.808 companhias abertas americanas, verificaram que 1.041 eram de estrutura de propriedade familiar. Dentre essas, $41,40 \%$ possuíam o CEO e o presidente do conselho de administração familiar.

De modo geral, o número de companhias que possuem gestão familiar, neste estudo, é significativo, principalmente quando comparado com o resultado encontrado em outras pesquisas anteriores. Uma gestão familiar, de acordo com a abordagem principal-agente da Teoria da Agência, poderá resultar em benefícios, pois o custo para reduzir as assimetrias de informação e o risco moral serão mais baixos e, assim, poderá influenciar para redução do custo de financiamento da dívida, conforme evidenciado por Ma, Ma e Tian (2017).

Todavia, pela perspectiva principal-principal, uma gestão familiar pode contribuir para o entrincheiramento familiar, aumentar a assimetria informacional entre famílias e minoritários e influenciar para aumento do custo da dívida, conforme os resultados apresentados nas pesquisas de Anderson, Mansi e Reeb (2003) e Lin et al. (2011).

O envolvimento do controlador na gestão, segundo Mork, Shleifer e Vishny (1988), é determinado pela influência que ele exerce nos principais cargos executivos, principalmente em relação ao cargo de CEO e de presidente do conselho de administração. Portanto, infere-se que, nas empresas da amostra, as famílias controladoras exercem influência significativa na gestão, visto que os percentuais de empresas com estrutura de propriedade familiar e que também possuem gestão familiar foram representativos.

$\mathrm{Na}$ Tabela 2, evidenciam-se as médias do custo da dívida das companhias com: a) estrutura de propriedade e diretor presidente familiar; b) estrutura de propriedade familiar e diretor presidente não familiar. 
Tabela 2 - Custo de financiamento da dívida do período de 2012 a 2016 das companhias com diretor presidente familiar e diretor presidente não familiar

\begin{tabular}{c|c|c|c|c|c|c|c|c}
\hline \multirow{2}{*}{$\begin{array}{c}\text { Custo da } \\
\text { dívida }\end{array}$} & \multicolumn{2}{c|}{$\begin{array}{c}\text { Diretor presidente } \\
\text { familiar }\end{array}$} & \multicolumn{2}{c|}{$\begin{array}{c}\text { Diretor presidente não } \\
\text { familiar }\end{array}$} & \multicolumn{2}{c|}{ Teste de Levene } & \multicolumn{2}{c}{ Teste-t } \\
\cline { 2 - 9 } & № & Média & No & Média & F & Sig & t & Sig \\
\hline 2016 & 69 & 0,52 & 56 & 0,77 & 3,34 & 0,07 & $-1,04$ & 0,09 \\
2015 & 67 & 0,50 & 56 & 0,83 & 6,48 & 0,01 & $-1,53$ & 0,03 \\
2014 & 67 & 0,29 & 56 & 0,51 & 14,51 & 0,00 & $-2,18$ & 0,03 \\
2013 & 65 & 0,29 & 51 & 0,52 & 10,12 & 0,00 & $-1,89$ & 0,06 \\
2012 & 65 & 0,28 & 48 & 0,43 & 5,99 & 0,02 & $-1,45$ & 0,05 \\
$2012-2016$ & 333 & 0,38 & 267 & 0,62 & 24,96 & 0,00 & $-3,15$ & 0,00 \\
\hline
\end{tabular}

Fonte: Dados da pesquisa.

$\mathrm{Na}$ Tabela 2, é possível observar que o teste de Levene indicou variâncias diferentes. Sendo assim, utilizaram-se os valores do Teste-t de variâncias iguais não assumidas, conforme orientam Hair Júnior et al. (2005), para os casos em que se assume a homogeneidade.

Em relação ao custo da dívida, inicialmente, ao comparar os dois grupos, percebe-se que as médias do primeiro grupo, das empresas que possuem o diretor presidente familiar, são estatisticamente inferiores às médias do segundo grupo, em todos os anos. Inclusive quando se comparam as médias de todo o período de 2012 a 2016 (0,38 e 0,62). Assim, depreende-se que, dentre as empresas familiares, àquelas com diretor presidente familiar possuem menor custo de financiamento da dívida.

Esses resultados indicam que as empresas com estrutura de propriedade familiar que não possuem diretor familiar podem estar sujeitas a maiores problemas de agência. Logo, acredita-se que o efeito alinhamento supera o efeito entrincheiramento nas companhias familiares quando o diretor presidente também é familiar.

$\mathrm{Na}$ Tabela 3, apresentam-se as médias do custo da dívida das companhias com: a) estrutura de propriedade e presidente do conselho de administração familiar; b) estrutura de propriedade familiar e presidente do conselho de administração não familiar.

Tabela 3 - Custo de financiamento da dívida do período de 2012 a 2016 das companhias com presidente do conselho de administração familiar e não familiar

\begin{tabular}{c|c|c|c|c|c|c|c|c|}
\hline \multirow{2}{*}{ Custo da dívida } & \multicolumn{2}{|c|}{$\begin{array}{c}\text { Presidente do } \\
\text { conselho familiar }\end{array}$} & \multicolumn{2}{c|}{$\begin{array}{c}\text { Presidente do } \\
\text { conselho não familiar }\end{array}$} & \multicolumn{2}{c|}{$\begin{array}{c}\text { Teste de } \\
\text { Levene }\end{array}$} & \multicolumn{3}{c}{ Teste-t } \\
\cline { 2 - 9 } & № & Média & № & Média & F & Sig & t & Sig \\
\hline 2016 & 85 & 0,61 & 40 & 0,72 & 0,34 & 0,56 & $-1,35$ & 0,07 \\
2015 & 83 & 0,58 & 40 & 0,95 & 4,15 & 0,04 & $-1,32$ & 0,05 \\
2014 & 85 & 0,35 & 38 & 0,55 & 3,83 & 0,05 & $-1,21$ & 0,07 \\
2013 & 87 & 0,32 & 29 & 0,95 & 22,75 & 0,00 & $-3,74$ & 0,00 \\
2012 & 83 & 0,29 & 30 & 0,70 & 20,62 & 0,00 & $-3,08$ & 0,00 \\
$2012-2016$ & 423 & 0,43 & 177 & 0,77 & 19,66 & 0,00 & $-2,80$ & 0,01 \\
\hline
\end{tabular}

Fonte: Dados da pesquisa.

$\mathrm{Na}$ Tabela 3, o teste de Levene, novamente, evidencia variâncias diferentes, visto que existem indicadores F significantes. Então, nesses casos foram utilizados os valores do Teste-t de variâncias iguais não assumidas. Para os anos em que o teste de Levene não foi significante foram utilizados os valores do Teste-t de variâncias iguais assumidas.

É possível perceber na Tabela 3 que em todos os anos as médias do primeiro grupo, das empresas que possuem o presidente do conselho familiar, são estatisticamente inferiores às médias do segundo grupo, em que o presidente do conselho de administração não é familiar. Portanto, dentre as empresas familiares, àquelas com presidente do conselho familiar possuem menor custo de financiamento da dívida.

Tais resultados demonstram, outra vez, que as empresas de estrutura familiar que não possuem gestão familiar podem estar sujeitas a maiores problemas de agência. Portanto, assim como ocorreu em relação à análise do diretor presidente, acredita-se que o efeito alinhamento supera o efeito entrincheiramento nas companhias familiares.

$\mathrm{Na}$ Tabela 4, apresentam-se as médias do custo da dívida das companhias com: a) estrutura de propriedade familiar, diretor presidente e presidente do conselho de administração também familiar; b) estrutura de propriedade familiar, mas com diretor presidente e presidente do conselho de administração não familiar.

O teste de Levene exposto na Tabela 4 permite averiguar que existem variâncias diferentes na maioria dos anos, visto que existem indicadores $\mathrm{F}$ significantes. Por isso, nesses casos foram utilizados os valores do Teste-t de variâncias iguais não assumidas. Para o ano em que o teste de Levene não foi significante foi utilizado o valor do Teste-t de variâncias iguais assumidas. 
É possível perceber na Tabela 4, ao comparar os dois grupos, que as médias do primeiro grupo, das empresas que também possuem o diretor presidente e o presidente do conselho de administração familiar, de forma combinada, são estatisticamente inferiores às médias do segundo grupo, em todos os anos. Inclusive quando se comparam as médias de todo o período de 2012 a 2016 (0,38 e 0,59). Portanto, no período de 2012 a 2016, de modo geral, quando o diretor presidente e o presidente do conselho de administração eram familiares, o custo da dívida nas companhias analisadas era inferior, logo, acredita-se que o efeito alinhamento, outra vez, supera o efeito entrincheiramento nas companhias familiares.

Tabela 4 - Custo de financiamento da dívida do período de 2012 a 2016 das companhias com estrutura de propriedade familiar, diretor presidente e presidente do conselho de administração também familiar e das companhias com diretor presidente e presidente do conselho de administração não familiar

\begin{tabular}{c|c|c|c|c|c|c|c|c}
\hline \multirow{2}{*}{$\begin{array}{c}\text { Custo da } \\
\text { dívida }\end{array}$} & \multicolumn{2}{|c|}{$\begin{array}{c}\text { Estrut_Fam, } \\
\text { DirPres_Fam e } \\
\text { PresCA_Fam }\end{array}$} & \multicolumn{2}{|c|}{$\begin{array}{c}\text { Estrut_Fam, } \\
\text { DirPres_NãoFam e } \\
\text { PresCA_NãoFam }\end{array}$} & \multicolumn{2}{|c|}{ Teste de Levene } & \multicolumn{2}{|c}{ Teste-t } \\
\cline { 2 - 10 } & No & Média & No & Média & F & Sig & t & Sig \\
\hline 2016 & 59 & 0,52 & 66 & 0,72 & 1,66 & 0,20 & $-1,78$ & 0,04 \\
2015 & 57 & 0,51 & 66 & 0,77 & 3,81 & 0,05 & $-1,28$ & 0,10 \\
2014 & 57 & 0,30 & 66 & 0,47 & 8,71 & 0,00 & $-1,89$ & 0,06 \\
2013 & 61 & 0,30 & 55 & 0,50 & 7,46 & 0,01 & $-1,72$ & 0,08 \\
2012 & 63 & 0,28 & 50 & 0,42 & 5,12 & 0,03 & $-1,48$ & 0,09 \\
$2012-2016$ & 297 & 0,38 & 303 & 0,59 & 16,77 & 0,00 & $-2,81$ & 0,01 \\
\hline
\end{tabular}

Fonte: Dados da pesquisa.

Na Tabela 5 estão expostos os coeficientes das regressões da influência da gestão familiar no custo da dívida das companhias da amostra.

Tabela 5 - Coeficientes das regressões da influência da gestão familiar no custo da dívida

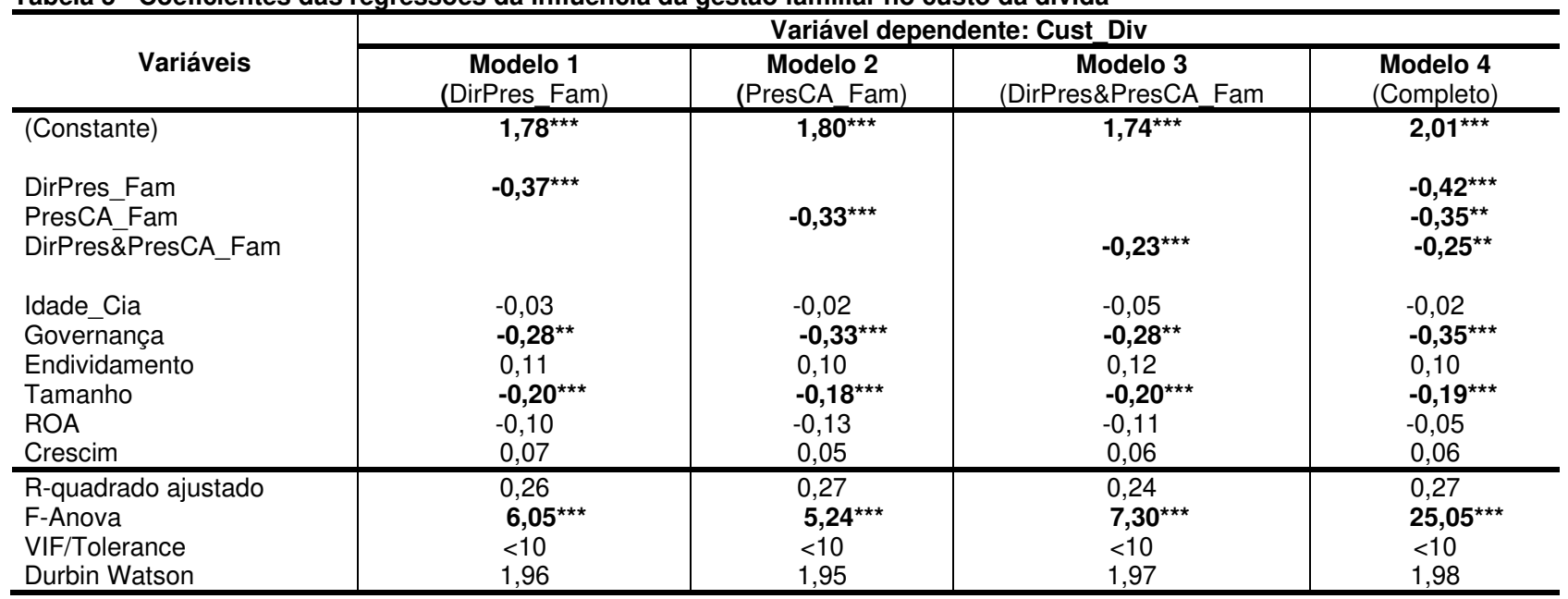

*** Significativo a $1 \% ;{ }^{* *}$ Significativo a $5 \% ;{ }^{*}$ Significativo a $10 \%$

Fonte: Dados da pesquisa.

É possível verificar na Tabela 5 que os $\mathrm{R}^{2}$ ajustados ficaram entre $24 \%$ e $27 \%$. Estes $\mathrm{R}^{2}$ ajustados são similares aos registrados em outras pesquisas anteriores da mesma natureza, tais como de Boubakri e Ghouma (2010), que possuíam $\mathrm{R}^{2}$ de 24 e $25 \%$, de Lin et al. (2011) com $\mathrm{R}^{2}$ entre $20 \%$ e $30 \%$, Hashim e Amrah (2016) com $\mathrm{R}^{2}$ de $21 \%$ e $35 \%$ e Ma, Ma e Tian (2017) que possuíam $\mathrm{R}^{2}$ de $20 \%$ e $30 \%$. Deste modo, o percentual explicado pelas variáveis independentes pode ser considerado aceitável.

Nota-se que os testes F-ANOVA foram significantes $(0,01)$, ou seja, o conjunto de variáveis independentes exerce influência sobre as variáveis dependentes em todos os modelos. Os resultados das estatísticas de Durbin-Watson (entre 1,95 e 1,98) demonstraram que não existem problemas de autocorrelação dos resíduos. Os fatores de inflação de variância (VIF e Tolerance) demonstram que não há problema de multicolinearidade entre as variáveis independentes dos modelos.

É possível observar, ainda na Tabela 5, que as três variáveis relacionadas ao tipo de gestão "DirPres_Fam", "PresCA_Fam" e "DirPres\&PresCA", que captam a presença de um membro da família ocupando o cargo de diretor presidente, o cargo de presidente do conselho de administração, ou quando os dois cargos estão sob domínio da família, respectivamente, revelaram-se significantes estatisticamente e com coeficientes negativos, seja quando analisadas de forma individual ou quando analisadas de forma conjunta. Estes resultados indicam que a gestão familiar influencia para redução do custo de financiamento da dívida, 
principalmente quando o diretor presidente é familiar, uma vez que os coeficientes foram mais elevados para esta variável.

Estes resultados fortalecem os achados da análise univariada deste estudo e estão em consonância com os resultados de Ma, Ma e Tian (2017), que também apontaram influência da gestão familiar para um menor custo da dívida em companhias abertas chinesas. Os resultados também estão alinhados com a perspectiva principal-agente da teoria da agência, ou seja, presume-se que em empresas situadas no Brasil, com estrutura de propriedade e gestão familiar, há maior alinhamento de interesses entre o controlador e o gestor. Então, quando o efeito alinhamento torna-se dominante o custo de financiamento da dívida tende a ser menor.

Dentre as variáveis de controle, verifica-se na Tabela 5 que apenas duas revelaram-se estatisticamente significantes. Trata-se das variáveis "Governança" e "Tamanho", que apresentaram coeficientes negativos. De modo contrário, as variáveis "Idade_Cia", "Endividamento", "ROA" e "Crescim" não apresentaram coeficientes estatisticamente significantes.

Em relação à governança corporativa, os resultados confirmam que boas práticas de governança podem contribuir para a redução de problemas de agência, da assimetria de informações e ajudar a proteger, inclusive, os interesses dos credores. Por isso, empresas que possuem melhores práticas de governança tendem a apresentar menores custos da dívida, conforme descrevem Barros, Silva e Voese (2015) e Fonseca e Silveira (2016).

No tocante ao tamanho das empresas, confirmou-se que empresas maiores, por se beneficiarem de economias de escala e desempenho estável. Também por apresentarem capacidade superior para suportar choques negativos nos fluxos de caixa, são vistas como menos arriscadas pelos credores e tendem a ter menores custos de financiamento da dívida, conforme argumentaram autores como Anderson, Mansi e Reeb (2003), Boubakri e Ghouma (2010), Lin et al. (2011), Tanaka (2014), Hashim e Amrah (2016) e Ma, Ma e Tian (2017).

\section{Considerações Finais}

O objetivo do estudo foi verificar a influência da gestão familiar no custo de financiamento da dívida de companhias abertas familiares listadas na B3. Para tal, realizou-se pesquisa descritiva, quantitativa e conduzida por meio de análise documental, com consulta aos Formulários de Referência, Banco de dados Economática, site da BM\&FBovespa e websites das organizações. A amostra foi composta por 113 companhias familiares em 2012, 116 em 2013, 123 em 2014, 123 em 2015 e 125 em 2016.

Os resultados revelaram que, no ano de 2011 , primeiro ano da análise, $58 \%$ das empresas familiares da amostra, também possuíam o diretor presidente familiar. Destaca-se que ao longo do período de 2011 a 2015 não ocorreram grandes variações, sendo que no ano de 2015, último ano da análise, 56\% das empresas possuíam o diretor presidente familiar.

Ao analisar o cargo de presidente do conselho de administração, percebeu-se que no ano de 2011, primeiro ano da análise, o percentual de empresas que possuíam o presidente do conselho também familiar foi de 73\%. Também não ocorreram grandes variações no período de 2011 a 2015 . No ano de 2015, último ano da análise, $69 \%$ delas possuíam o presidente do conselho familiar.

No que se refere aos cargos de diretor presidente e presidente do conselho de administração (DirPres\&PresCA_Fam), de forma combinada, verificou-se que, no ano de $2011,56 \%$ das empresas possuíam estes cargos ocupados pelo fundador ou por um membro da família. Outra vez, não ocorreram grandes variações no período de 2011 a 2015. No ano de 2015, 48\% das empresas possuíam o CEO e o presidente do conselho de administração familiar.

De modo geral, o número de companhias que possuíam gestão familiar, neste estudo, foi significativo. Nesse sentido, é importante ressaltar que o envolvimento do controlador na gestão, segundo Mork et al. (1988), é determinado pela influência que ele exerce nos principais cargos executivos, principalmente em relação ao cargo de CEO e de presidente do conselho de administração. Portanto, infere-se que, nas empresas da amostra, as famílias controladoras exerciam influência significativa na gestão, visto que os percentuais de empresas com estrutura de propriedade familiar, que também possuíam gestão familiar foram representativos.

Quanto ao custo de financiamento da dívida, ao considerar as empresas com diretor presidente familiar, aquelas que possuem o presidente do conselho de administração familiar e, ainda, aquelas que possuem ambos de forma combinada, diretor presidente e presidente do conselho de administração familiar, constatou-se que as empresas que possuíam gestão familiar também apresentaram, na maioria dos anos analisados, um custo da dívida menor, quando comparadas com empresas de gestão não familiar.

Portanto, os resultados indicam que na amostra da pesquisa prevalece a abordagem principal-agente da teoria da agência, em que um maior alinhamento entre controle e gestão (controle familiar e gestão familiar) resulta em benefícios, pois o custo para reduzir as assimetrias informacionais e o risco moral tornam-se mais baixos e, assim, há influência para redução do custo de financiamento da dívida, conforme evidenciado por Ma, Ma e Tian (2017). 
No que tange a influência da gestão familiar no custo da dívida, percebeu-se que as três variáveis que captavam a existência de gestão familiar revelaram-se significantes estatisticamente e com coeficientes negativos. Assim, os resultados indicaram que a gestão familiar influenciava para redução do custo de financiamento da dívida.

Estes resultados fortaleceram os achados da análise univariada do estudo e estão em consonância com os resultados de Ma, Ma e Tian (2017), que também apontaram influência da gestão familiar para um menor custo da dívida. Os resultados também estão alinhados com a perspectiva principal-agente da Teoria da Agência, ou seja, presume-se que empresas situadas no Brasil, com estrutura de propriedade e gestão familiar, desfrutam de maior alinhamento de interesses entre o controlador e o gestor. Quando o efeito alinhamento torna-se dominante o custo da de financiamento da dívida tende a ser menor.

Apesar do rigor científico e dos cuidados metodológicos, a pesquisa apresenta limitações. Por exemplo, para identificar o tipo de estrutura de propriedade adotou-se um percentual mínimo de $10 \%$ dos direitos de voto. No entanto, alguns autores, de forma mais conservadora, utilizaram-se de outros percentuais superiores, como Schmid (2013) e Ma, Ma e Tian (2017) que consideraram um percentual mínimo de $20 \%$.

Então, recomenda-se para pesquisas futuras, que considerem percentuais superiores, assim como Schmid (2013) e Ma, Ma e Tian (2017) que consideraram um percentual mínimo de $20 \%$, ou, ainda, um percentual mínimo de 50\%, assim como no estudo de Steijvers e Voordeckers (2009). Também seria interessante investigar a influência de outros tipos de acionistas no custo de financiamento da dívida, como investidores institucionais ou propriedade governamental, por exemplo.

Para identificação e análise da gestão familiar adotou-se neste estudo a metodologia de Villalonga e Amit (2006), que investigaram a participação das famílias na diretoria executiva e no conselho de administração. Todavia, não foram consideradas nesta pesquisa, diferenças entre fundadores e descendentes. Logo, recomenda-se fazer tais distinções.

Além disso, sugere-se ainda ampliar o número de empresas pesquisadas e utilizar outros períodos de tempo, a fim de identificar tendências no custo de financiamento da dívida de companhias nacionais familiares e não familiares. No entanto, apesar das limitações deste estudo, o tema pesquisado é relevante e não invalida os resultados obtidos, que podem servir como referência para estudos posteriores, principalmente pela aplicação de novas técnicas.

\section{Referências}

ANDERSON, Ronald C.; MANSI, Sattar A.; REEB, David M. Founding family ownership and the agency cost of debt. Journal of Financial Economics, v. 68, n. 2, p. 263-285, 2003. https://doi.org/10.1016/S0304405X(03)00067-9.

ANGONESE, Rodrigo; FANK, Odir L.; OLIVEIRA, Cosmo R.; BEZERRA, Francisco A. Divulgação de informações voluntárias na internet como determinante do custo do capital de terceiros. Enfoque: Reflexão Contábil, v. 32, n. 3, 2013.

ARDALAN, Kavous. Capital structure theory: reconsidered. Research in International Business and Finance, v. 39, p. 696-710, 2017. https://doi.org/10.1016/j.ribaf.2015.11.010.

BARONTINI, Roberto; CAPRIO, Lorenzo. The effect of family control on firm value and performance: Evidence from continental Europe. European Financial Management, v. 12, n. 5, p. 689-723, 2006. https://doi.org/10.1111/j.1468-036X.2006.00273.x.

BARROS, Claudio M. E.; SILVA, Pedro Y. C.; VOESE, Simone B. Relação entre o custo da dívida de financiamentos e governança corporativa no Brasil. Contabilidade, Gestão e Governança, v. 18, n. 2, 2015.

BLISS, Mark A.; GUL, Ferdinand A. Political connection and cost of debt: Some Malaysian evidence. Journal of Banking \& Finance, v. 36, n. 5, p. 1520-1527, 2012.

https://doi.org/10.1016/j.jbankfin.2011.12.011.

BOUBAKRI, Narjess; GHOUMA, Hatem. Control/ownership structure, creditor rights protection, and the cost of debt financing: International evidence. Journal of Banking \& Finance, v. 34, n. 10, p. 2481-2499, 2010. https://doi.org/10.1016/j.jbankfin.2010.04.006.

BRADLEY, Daniel; PANTZALIS, Christos; YUAN, Xiaojing. The influence of political bias in state pension funds. Journal of Financial Economics, v. 119, n. 1, p. 69-91, 2016.

https://doi.org/10.1016/j.jfineco.2015.08.017. 
BYUN, Hae-Young; CHOI, Sunhwa; HWANG, Lee-Seok; KIM, Robert G. Business group affiliation, ownership structure, and the cost of debt. Journal of Corporate Finance, v. 23, p. 311-331, 2013. https://doi.org/10.1016/j.jcorpfin.2013.09.003.

CAI, Di; LUO, Jin-hui; WAN, Di-fang. Family CEOs: Do they benefit firm performance in China? Asia Pacific Journal of Management, v. 29, n. 4, p. 923-947, 2012. https://doi.org/10.1007/s10490-012-9318-4.

CAROPREZO, Bruno. O impacto das melhores práticas de governança corporativa no custo da dívida das empresas brasileiras. Tese de Doutorado, Escola de Pós-Graduação em Economia, Fundação Getúlio Vargas, 2011.

CASTRO, Miguel Angel Rivera; MARTINEZ, Antonio Lopo. Income smoothing, cost of debt capital and capital structure in Brazil. RAM. Revista de Administração Mackenzie, v. 10, n. 6, p. 25-46, 2009. https://doi.org/10.1590/S1678-69712009000600004.

CHEN, Z.; PAN, J.; WANG, L.; SHEN, X. Disclosure of government financial information and the cost of local government's debt financing - Empirical evidence from provincial investment bonds for urban construction. China Journal of Accounting Research, v. 9, n. 3, p. 191-206, 2016 https://doi.org/10.1016/j.cjar.2016.02.001.

DÍAZ-DÍAZ, Nieves Lidia; GARCÍA-TERUEL, Pedro J.; MARTíNEZ-SOLANO, Pedro. Debt maturity structure in private firms: Does the family control matter? Journal of Corporate Finance, v. 37, p. 393-411, 2016. https://doi.org/10.1016/j.jcorpfin.2016.01.016.

DERRIEN, François; KECSKÉS, Ambrus; MANSI, Sattar A. Information asymmetry, the cost of debt, and credit events: Evidence from quasi-random analyst disappearances. Journal of Corporate Finance, v.39, p.295-311, 2016. https://doi.org/10.1016/j.jcorpfin.2016.05.002.

DURAND, David. Costs of debt and equity funds for business: trends and problems of measurement. In: Conference on Research in Business Finance. NBER, p. 215-262, 1995. Proceedings..., 1995.

FAN, Joseph PH; WEI, KC John; XU, Xinzhong. Corporate finance and governance in emerging markets: A selective review and an agenda for future research. Journal of Corporate Finance, v. 17, n. 2, p. 207-214, 2011. https://doi.org/10.1016/j.jcorpfin.2010.12.001.

FERNANDES, Sheila M. A influência do disclosure ambiental na estrutura de capital das empresas brasileiras listadas na BM\&FBovespa. Sociedade, Contabilidade e Gestão, v. 7, n. 2, 2013.

FONSECA, Camila V. C.; SILVEIRA, Rodrigo L. F. Governança Corporativa e Custo de Capital de Terceiros: Evidências entre Empresas Brasileiras de Capital Aberto. REAd-Revista Eletrônica de Administração, v. 22, n. 1, 2016. https://doi.org/10.1590/1413-2311.016162016.62739.

GE, Wenxia; LIU, Mingzhi. Corporate social responsibility and the cost of corporate bonds. Journal of Accounting and Public Policy, v. 34, n. 6, p. 597-624, 2015. https://doi.org/10.1016/j.jaccpubpol.2015.05.008.

GHOUMA, Hatem; BEN-NASR, Hamdi; YAN, Ruiqian. Corporate governance and cost of debt financing: Empirical evidence from Canada. The Quarterly Review of Economics and Finance, 2017. https://doi.org/10.1016/j.qref.2017.06.004.

GONZÁLEZ, Maximiliano; GUZMÁN, Alexander; POMBO, Carlos; TRUJILLO, María-Andrea. A. Family firms and debt: Risk aversion versus risk of losing control. Journal of Business Research, v. 66, n. 11, p. 23082320, 2013. https://doi.org/10.1016/j.jbusres.2012.03.014.

GRAHAM, John R.; LEARY, Mark T.; ROBERTS, Michael R. A century of capital structure: The leveraging of corporate America. Journal of Financial Economics, v. 118, n. 3, p. 658-683, 2015.

https://doi.org/10.1016/j.jfineco.2014.08.005.

HAIR JÚNIOR, Joseph F.; ANDERSON, Rolph E.; TATHAM, Ronald L.; BLACK, William C. Análise multivariada de dados. 5. ed. Porto Alegre: Bookman, 2005. 
HAMID, Masdiah A.; ABDULLAH, Azizah; KAMARUZZAMAN, Nur A. Capital structure and profitability in family and non-family firms: Malaysian evidence. Procedia Economics and Finance, v. 31, p. 44-55, 2015. https://doi.org/10.1016/S2212-5671(15)01130-2.

HASHIM, Hafiza A.; AMRAH, Muneer. Corporate governance mechanisms and cost of debt: Evidence of family and non-family firms in Oman. Managerial Auditing Journal, v. 31, n. 3, p. 314-336, 2016. https://doi.org/10.1108/MAJ-12-2014-1139.

IATRIDIS, George E. Audit quality in common-law and code-law emerging markets: evidence on earnings conservatism, agency costs and cost of equity. Emerging Markets Review, v. 13, n. 2, p. 101-117, 2012. https://doi.org/10.1016/j.ememar.2012.01.001.

JENSEN, Michael C.; MECKLING, William H. Theory of the firm: Managerial behavior, agency costs and ownership structure. Journal of Financial Economics, v. 3, n. 4, p. 305-360, 1976.

https://doi.org/10.1016/0304-405X(76)90026-X.

KHAN, Muhammad K.; KALEEM, Ahmad; NAZIR, MianSajid; SAEED, Rashid. Relationship of family ownership and agency cost of debt in pakistani firms. Science International, v. 25, n. 2, 2013.

KONRAHT, Jonatan M.; CAMARGO, Raphael V. W.; VICENTE, Ernesto F. R. Excesso de controle acionário: um estudo do seu reflexo sobre o custo da dívida das empresas brasileiras de capital aberto. Enfoque, v. 35, n. 2, p. 105, 2016.

LA PORTA, Rafael; LOPEZ-DE-SILANES, Florencio; SHLEIFER, Andrei. Corporate ownership around the world. The Journal of Finance, v. 54, n. 2, p. 471-517, 1999. https://doi.org/10.1111/0022-1082.00115.

LAI, Kam-Wah. The cost of debt when all-equity firms raise finance: The role of investment opportunities, audit quality and debt maturity. Journal of Banking \& Finance, v. 35, n. 8, p. 1931-1940, 2011. https://doi.org/10.1016/j.jbankfin.2011.01.007.

LE, Thi P. V.; BICH, Nguyet P. T. Capital Structure and Firm performance: Empirical evidence from a developing country. Research in International Business and Finance, v. 10, n. 16, 2017. https://doi.org/10.1016/j.ribaf.2017.07.012.

LI, S.; RICHIE, N. Income smoothing and the cost of debt. China Journal of Accounting Research, v. 9, n.3, p. 175-190, 2017. https://doi.org/10.1016/j.cjar.2016.03.001.

LIEDONG, Tahiru A.; RAJWANI, Tazeeb. Mediation in the Link Between Political Ties and Cost of Debt in Ghana: An Agency Perspective. In: Academy of Management Proceedings. Briarcliff Manor, NY 10510: Academy of Management, 2017. p. 15447.

LIMA, Gerlando A. S. F. Nível de evidenciação x custo da dívida das empresas brasileiras. Revista Contabilidade \& Finanças, v. 20, n.49, p. 95-108, 2009. http://dx.doi.org/10.1590/S151970772009000100007 .

LIN, Chen; MA, Yue; MALATESTA, Paul; XUAN, Yuhai. Ownership structure and the cost of corporate borrowing. Journal of Financial Economics, v. 100, n. 1, p. 1-23, 2011.

https://doi.org/10.1016/j.jfineco.2010.10.012.

LIU, Weiping; YANG, Haibin; ZHANG, Guangxi. Does family business excel in firm performance? An institution-based view. Asia Pacific Journal of Management, v. 29, n. 4, p. 965-987, 2012.

https://doi.org/10.1007/s10490-010-9216-6.

MA, Liangbo; MA, Shiguang; TIAN, Gary. Corporate opacity and cost of debt for family firms. European Accounting Review, v. 26, n. 1, p. 27-59, 2017. https://doi.org/10.1080/09638180.2015.1087868.

MAZZI, Chiara. Family business and financial performance: Current state of knowledge and future research challenges. Journal of Family Business Strategy, v. 2, n. 3, p. 166-181, 2011.

https://doi.org/10.1016/j.jfbs.2011.07.001.

MCCONAUGHY, Daniel L. Family CEOs vs. nonfamily CEOs in the family-controlled firm: An examination of the level and sensitivity of pay to performance. Family Business Review, v. 13, n. 2, p. 121-131, 2000.

https://doi.org/10.1111/j.1741-6248.2000.00121.x. 
MODIGLIANI, Franco; MILLER, Merton H. The cost of capital, corporation finance and the theory of investment. The American Economic Review, v. 48, n. 3, p. 261-297, 1958.

MOURA, Geovanne D. Influência da estrutura de propriedade e da gestão familiar no posicionamento em fusões e aquisições. 468 f. 2014. Tese de Doutorado. Universidade Regional de Blumenau, Blumenau, 2014.

MOURA, Geovanne D.; MACÊDO, Francisca F. R. R., MAZZIONI, Sady; KRUGER, Silvana D. Análise da relação entre gerenciamento de resultados e custo de capital em empresas brasileiras listadas na BM\&FBOVESPA. Revista Catarinense da Ciência Contábil, v.15, n.44, p.09-23, 2016. http://dx.doi.org/10.16930/2237-7662/rccc.v15n44p9-23.

MYERS, Stewart C. The capital structure puzzle. The Journal of Finance, v. 39, n. 3, p. 574-592, 1984. https://doi.org/10.1111/j.1540-6261.1984.tb03646.x.

MYERS, Stewart C.; MAJLUF, Nicholas S. Corporate financing and investment decisions when firms have information that investors do not have. Journal of Financial Economics, v. 13, n. 2, p. 187-221, 1984. http://doi.org/10.3386/w1396.

NARDI, Paula C. C.; NAKAO, Silvio H. Gerenciamento de resultados e a relação com o custo da dívida das empresas brasileiras abertas. Revista Contabilidade \& Finanças, v. 20, n. 51, 2009.

https://doi.org/10.1590/S1519-70772009000300006.

PENG, Mike W.; JIANG, Yi. Institutions behind family ownership and control in large firms. Journal of Management Studies, v. 47, n. 2, p. 253-273, 2010. https://doi.org/10.1111/j.1467-6486.2009.00890.x.

SANTOS, Edilene S.; PONTE, Vera M. R.; MAPURUNGA, Patrícia V. R. Adoção obrigatória do IFRS no Brasil (2010): índice de conformidade das empresas com a divulgação requerida e alguns fatores explicativos. Revista Contabilidade \& Finanças, v. 25, n. 65, 2014. https://doi.org/10.1590/S151970772014000200006 .

SCHMID, Thomas. Control considerations, creditor monitoring, and the capital structure of family firms. Journal of Banking \& Finance, v. 37, n. 2, p. 257-272, 2013.

https://doi.org/10.1016/j.jbankfin.2012.08.026.

SHAILER, Greg; WANG, Kun. Government ownership and the cost of debt for Chinese listed corporations. Emerging Markets Review, v. 22, p. 1-17, 2015.

https://doi.org/10.1016/j.ememar.2014.11.002.

SILVEIRA, A. Roteiro básico para apresentação e editoração de teses, dissertações e monografias. $2^{\mathrm{a}}$ Ed. Blumenau: Edifurb, 2004.

SIREGAR, Sylvia V.; UTAMA, Sidharta. Type of earnings management and the effect of ownership structure, firm size, and corporate-governance practices: Evidence from Indonesia. The International Journal of Accounting, v. 43, n. 1, p. 1-27, 2008. https://doi.org/10.1016/j.intacc.2008.01.001.

STEIJVERS, Tensie; VOORDECKERS, Wim. Private family ownership and the agency costs of debt. Family Business Review, v. 22, n. 4, p. 333-346, 2009. https://doi.org/10.1177/0894486509338291.

TANAKA, Takanori. Corporate governance and the cost of public debt financing: Evidence from Japan. Journal of the Japanese and International Economies, v. 34, p. 315-335, 2014. https://doi.org/10.1016/j.jjie.2014.03.002.

VILLALONGA, Belen; AMIT, Raphael. How do family ownership, control and management affect firm value? Journal of Financial Economics, v. 80, n. 2, p. 385-417, 2006.

https://doi.org/10.1016/j.jfineco.2004.12.005.

VO, Xuan V. Determinants of capital structure in emerging markets: Evidence from Vietnam. Research in International Business and Finance, v. 40, p. 105-113, 2017. https://doi.org/10.1016/j.ribaf.2016.12.001.

YOUNG, Michael N.; PENG, Mike W.; AHLSTROM, David; BRUTON, Garry D.; JIANG, Yi. Corporate governance in emerging economies: A review of the principal-principal perspective. Journal of 
Management Studies, v. 45, n. 1, p. 196-220, 2008. https://doi.org/10.1111/j.1467-6486.2007.00752.x.

WAISMAN, Maya. Product market competition and the cost of bank loans: Evidence from state antitakeover laws. Journal of Banking \& Finance, v. 37, n. 12, p. 4721-4737, 2013.

https://doi.org/10.1016/j.jbankfin.2013.08.014.

\section{NOTAS}

\section{AGRADECIMENTOS}

Os autores agradecem as contribuições dos pareceristas anônimos do XVIII USP International Conference in Accounting e da Revista Contemporânea de Contabilidade, que possibilitaram uma série de melhorias ao artigo.

\section{CONTRIBUIÇÃO DE AUTORIA}

Concepção e elaboração do manuscrito: G. D. Moura, J. Lanzarin, S. Mazzioni, F. F. R. R. Macêdo

Coleta de dados: G. D. Moura, J. Lanzarin, S. Mazzioni, F. F. R. R. Macêdo

Análise de dados: G. D. Moura, J. Lanzarin, S. Mazzioni, F. F. R. R. Macêdo

Discussão dos resultados: G. D. Moura, J. Lanzarin, S. Mazzioni, F. F. R. R. Macêdo

Revisão e aprovação: G. D. Moura, J. Lanzarin, S. Mazzioni, F. F. R. R. Macêdo

\section{CONJUNTO DE DADOS DE PESQUISA}

O conjunto de dados que dá suporte aos resultados deste estudo não está disponível publicamente.

\section{FINANCIAMENTO}

Não se aplica.

\section{CONSENTIMENTO DE USO DE IMAGEM}

Não se aplica.

\section{APROVAÇÃO DE COMITÊ DE ÉTICA EM PESQUISA \\ Não se aplica.}

\section{CONFLITO DE INTERESSES}

Não se aplica.

\section{LICENÇA DE USO}

Os Direitos Autorais para artigos publicados neste periódico são do autor, com direitos de primeira publicação para a Revista. Em virtude de aparecerem nesta Revista de acesso público, os artigos são de uso gratuito, com atribuições próprias, em aplicações educacionais, de exercício profissional e para gestão pública. A Revista adotou a licença Creative Commons Atribuição 4.0 Internacional - CC BY NC ND. Esta licença permite acessar, baixar (download), copiar, imprimir, compartilhar, reutilizar e distribuir os artigos desde que com a citação da fonte, atribuindo os devidos créditos de autoria. Nesses casos, nenhuma permissão é necessária por parte dos autores ou dos editores. Autores têm autorização para assumir contratos adicionais separadamente, para distribuição não-exclusiva da versão do trabalho publicada nesta revista (ex.: publicar em repositório institucional ou um capítulo de livro).

\section{PUBLISHER}

Universidade Federal de Santa Catarina. Curso de Ciências Contábeis e Programa de Pós-graduação em Contabilidade. Publicação no Portal de Periódicos UFSC. As ideias expressadas neste artigo são de responsabilidade de seus autores, não representando, necessariamente, a opinião dos editores ou da universidade.

\section{EDITORES}

Carlos Eduardo Facin Lavarda e Suliani Rover

\section{HISTÓRICO}

Recebido em: 15/06/2018 - Revisado por pares em: 21/04/2020 - Reformulado em: 05/05/2020 Recomendado para publicação em: 05/06/2020 - Publicado em: 30/06/2020

Uma versão preprint do artigo foi apresentada no XVIII USP International Conference in Accounting, 2018. 